\title{
CHARACTERIZATION BY FACTOR ANALYSIS OF THE CHEMICAL FACIES OF GROUNDWATER IN THE DELTAIC PLAIN SANDS AQUIFER OF WARRI, WESTERN NIGER DELTA, NIGERIA
}

\author{
Olobaniyi, S.B. * and Owoyemi, F.B.** \\ *Department of Geology, Delta State University, P.M.B. 1, Abraka, Delta State, Nigeria \\ **Department of Petroleum Engineering and Geosciences, Petroleum Training Institute \\ P.M.B 20, Effurun, Delta State
}

\begin{abstract}
This paper examines the hydrochemical facies of groundwater present in the Deltaic Plain Sands aquifer of Warri and its immediate environs, maps their areal distribution and attempts to explain the controlling processes responsible for the various facies. 60 water samples were collected from wells tapping the Deltaic Plain Sands aquifer of Warri and environs and analyzed for various parameters including $\mathrm{pH}$, total dissolved solids (TDS), $\mathrm{K}, \mathrm{Na}, \mathrm{Ca}, \mathrm{Mg}, \mathrm{Cl}, \mathrm{HCO}_{3}$ and $\mathrm{SO}_{4}$ after standard procedures. The data obtained were subjected to R-mode factor analysis. Three factors were extracted. Factor 1 includes $\mathrm{K}, \mathrm{Na}, \mathrm{Cl}$, and $\mathrm{EC}$ and reflects the signature of saline water incursion resulting from seepages into the aquifer of water from the tide-influenced River Warri. Factor 2 has high loading values of $\mathrm{Mg}, \mathrm{Ca}, \mathrm{HCO}_{3}$ and $\mathrm{pH}$ and represents the processes of natural rainwater recharge and water-soil/rock interaction. Factor 3 includes $\mathrm{SO}_{4}$ and can be related to the dissolution of sulphides from interstratified peat within the geological formation, heavy vehicular activity and the petroleum refining process in the town. The areal distributions of the various factor scores indicate that factors 1 and 2 are enhanced close to the banks of River Warri and decreases away from them. A broad zone of groundwater interaction (mixing) between water species represented by factors 1 and 2 is thus created towards the riverbanks. The implication of this is that ionic concentration in the water decreases away from the banks of the river an indication that the quality of groundwater improves away from the river. Factor 3 is enhanced in the southeastern portion of the town where it is deemed to be caused by the dissolution by groundwater of sulphur bearing minerals within the geological formaton, and also in the central and northwestern portions of the town were it could be related to the rain-dissolution of sulphur bearing compounds from gaseous emanations arising from vehicles and the petroleum refining process respectively, which eventually as acid-rain recharges aquifers in the vicinity. This paper demonstrates the effectiveness of factor analysis in evaluating hydrochemical processes in coastal and industrial areas
\end{abstract}

\section{INTRODUCTION}

Water in its pure form is $\mathrm{H}_{2} \mathrm{O}$. By reason of its good solvent attribute, this composition is modified as it passes through the atmosphere and percolates the ground dissolving soluble materials of varying compositions along its flow path. Chebotarev (1955) has shown that bearing local variations, which may result from an abnormal concentration of certain constituents in the soil, the composition of groundwater varies from bicarbonate at outcrops to sulphate water at intermediate depths to chloride waters at greater depths of continuous flow. These changes reflect the signatures of one or some of such factors as soil/rock composition, prevailing climatic condition, $\mathrm{pH}$, the resident time of water within the formation and topography (Davis and De Wiest, 1966; Todd 1980; Raji and Alagbe, 1997). In coastal environments the influence of saltwater intrusion is often significant. The overall implication of this is that the hydrochemical facies of groundwater changes in response to its flow path history. 
Early studies on the characterization of groundwater facies and chemical evolutionary history utilized graphical representations of major ionic composition of groundwater (Piper, 1944; Stiff, 1951; Schoeller, 1962; Hem, 1989). These schemes were useful in visually describing differences in major-ion chemistry in groundwater and classifying water compositions into identifiable groups (Freeze and Cherry, 1979), which are usually of similar genetic history. Recently, factor analysis has been used with remarkable success as a tool in the study of groundwater chemistry. Factor analysis assumes that observed variables are products of linear combinations of some few underlying sources variables known as factors. It therefore attempts to find out these factors, which can explain a large amount of the variance of the analytical data. The effectiveness of factor analysis in hydrochemical studies has been aptly demonstrated in several studies. These include the delineation of zones of natural recharge to groundwater in the Floridan aquifer (Lawrence and Upchurch, 1983), the delineation of areas prone to salinity hazard in Chitravati watershed of India (Briz-Kishore and Murali, 1992) and the delineation of effluent contaminated groundwater at two industrial sites at Vasakhapatnam in India (Sabbarao et al, 1996). The effectiveness of this method in groundwater chemistry discrimination over the traditional piper and stiffs schemes stems from its ability to reveal hidden inter-variable relationships and allows the use of virtually limitless numbers of variable, thus trace elements and physical parameters can be part of the classification parameters. By its use of raw data as variable inputs, errors arising from close number systems are avoided. Also because elements are treated as independent variables, the masking effect of chemically similar elements that are often grouped together is avoided (Dalton and Upchurch, 1978).

The objective of this paper is to establish using factor analysis, the hydrochemical facies of groundwater present in the shallow Deltaic Plain Sands aquifer of Warri, to map their spatial distribution and attempt to explain the hydrochemical processes responsible for their evolution. This insight hopefully would aid in ensuring better water resource management in Warri and its immediate environs.

\section{STUDY AREA}

\section{Geographical Setting}

Warri is located in the western portion and coastal zone of the Nigerian Niger Delta (Figure 1) some 40 kilometres away from the shores of the Atlantic Ocean. The town has a population of over 300,000 people. This town is a prominent centre of commercial activities in southern
Nigeria. It has a port, a petroleum refining industry and several oil fields in its environs.

Warri occupies a low-lying area with height generally below six metres above sea level. The area is drained by River Warri and its network of tributaries and creeks, which empties into the sea (Figure 2). The drainage pattern is dendritic with tributaries branching without a preferred orientation. This signifies a homogeneous underlying material where structural control is lacking. The river is perennial and tide-influenced. As a result of the fresh water-salt water mixture, a brackish environment is created at the banks of the river and associated creeks. Consequently, vegetation along the banks is made up of mangrove plants of different species. Away from the banks rainforest plants predominate.

\section{Geology and Hydrogeology}

Warri is underlain by a sequence of sedimentary formations with a thickness of about 8000 metres and include from bottom to top, Akata Formation, Agbada Formation, Benin Formation and the Somebreiro-Warri Deltaic Plan Sands (Allen, 1965; Reyment, 1965; Short and Stauble,1967; Weber and Daukuro,1975).

The Akata Formation rests unconformably on the migmatite-gniess basement complex and forms the basal unit of the Niger delta statigraphic pile. This formation consists of an open marine facies unit dominated by highpressured carbonaceous shales. The formation ranges in age from Palaeocene to Eocene and its thickness could exceed 1000metres. The Agbada Formation consists of a sequence of alternating deltaic sands and shales. It is Eocene to Oligocene in age and exceeds 3000metres in thickness. This formation is the oil-reservoir in the Niger delta basin. The Benin Formation is Oligocene to Pleistocene in age. It consists predominantly of freshwater continental friable sands and gravel that are of excellent aquifer properties, with occasional intercalaton of shales. This formation contains the most productive and hence most tapped aquifer in the Niger delta region especially in areas north of Warri where it is shallow. The thickness of the Benin Formation is variable but generally exceeds 2000 metres.

Directly underlying the Warri area and the topmost of the sedimentary formation is the Quaternary to Recent alluvium, the Somebreiro-Warri Deltaic Plain Sands (Wigwe, 1975). This formation consists of fine to medium and coarse-grained unconsolidated sands that are often feldspathic (with 30 - $40 \mathrm{wt} \%$ feldspars) and occasionally gravelly. This sequence is locally stratified with peat and 


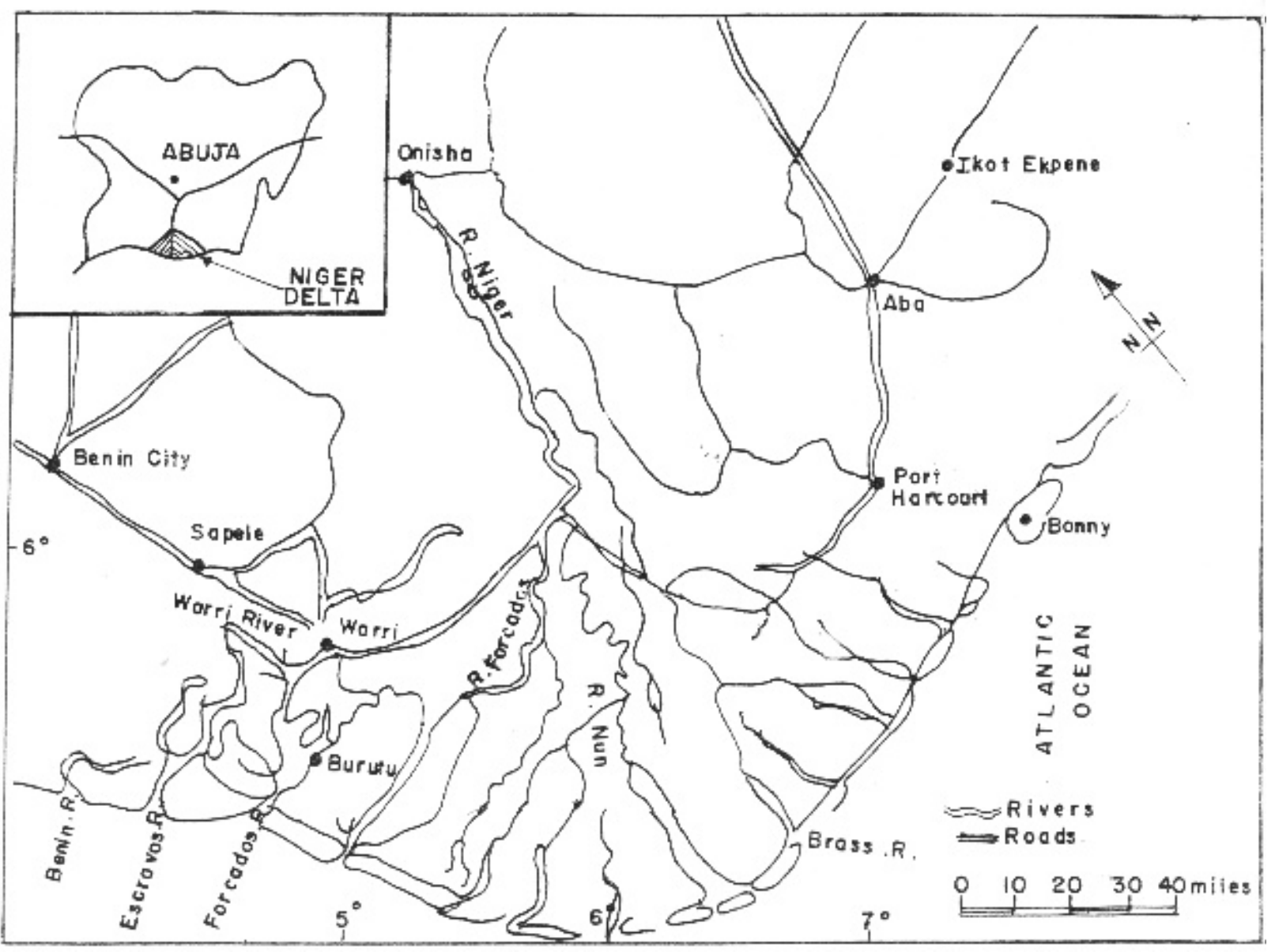

Figure 1: Geographical Map of the Niger Delta Region showing Warri inset: Map of Nigeria showing the Niger Delta

lenses of soft and plastic clay that could be sandy,and shales. The formation generally does not exceed 120 metres in thickness and it is predominantly unconfined. The hydraulic conductivities of the sand vary from $3.82 \times 10^{-3}$ to $9.0 \times 10^{-2} \mathrm{~cm} / \mathrm{sec}$, which indicates a potentially productive aquifer. Specific capacities recorded from different areas within this formation vary from $6700 \mathrm{lit} / \mathrm{hr} / \mathrm{m}$ to 13,500 lit/ $\mathrm{hr} / \mathrm{m}$ (Offodile, 1991). The water table is very close to the ground surface and varies from 0 to 4 metres. This limited groundwater level fluctuation reflects the high amounts of precipitation often recorded in the Warri area over the greater part of the year. Recent studies( Figure 2) have shown that this formation is partly recharged from River Warri (Olobaniyi and Owoyemi, in press)

\section{METHODOLOGY}

60 water samples obtained from shallow wells $(<50 \mathrm{~m})$ tapping the Somebreiro-Warri Deltaic Plain Sands aquifer of Warri and immediate environs were analyzed for both physical and chemical parameters. These parameters including total dissolved solids (TDS), $\mathrm{pH}$, sodium, potassium, calcium, magnesium, chloride and bicarbonate were determined according to standard specifications prescribed by the American Public Health Association (1985).

Data obtained from the laboratory analysis were used as variable inputs for factor analysis. Factor analysis was performed using the SPSS package described by Nie et al. (1975). Prior to the analysis, the data were standardized to produce a normal distribution of all variables (Davis, 


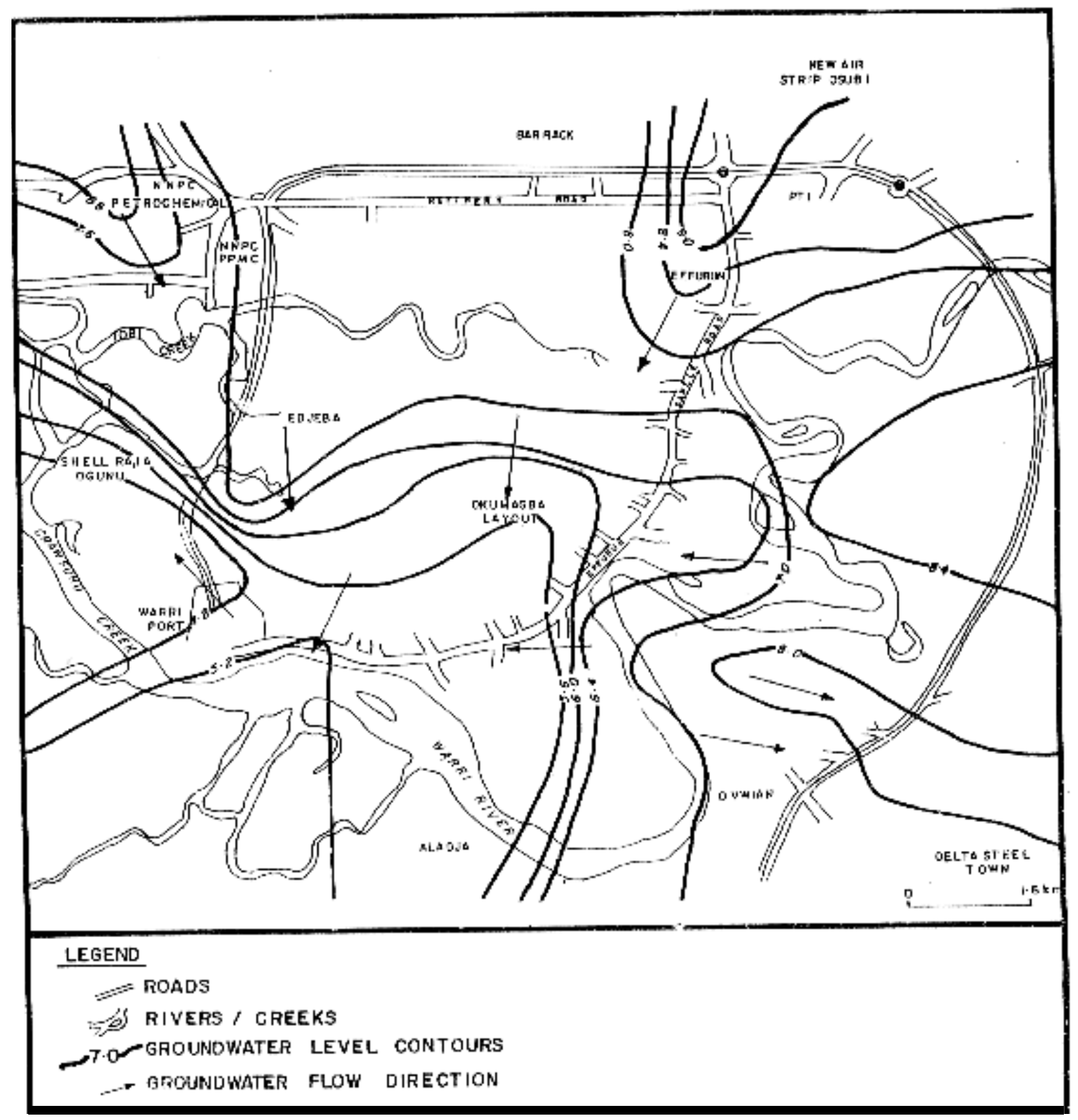

Figure 2: Groundwater Level Contour Map of Warri and Environs 
Characterization by Factor Analysis of the Chemical Facies of Groundwater in the Deltaic Plain Sands Aquifer of Warri, Western Niger Delta, Nigeria

1973). This was followed by a preparation of a correlation matrix of the data from which initial factor solutions were extracted by the principal component analytical method. Factor extraction was done with a minimum acceptable eigenvalue as 1 (Kaiser, 1958; Harman, 1960). Orthogonal rotation of these initial factors to terminal factor solutions (Table 1) was done with Kaiser's varimax scheme (Kaiser, 1958). This method maximizes the variance of the loadings on the factors and hence adjusts them to be either near \pm 1 or near zero (Davis, 1973). Factor score coefficients are derived from the factor loadings. Factor scores are computed for each sample by a matrix multiplication of the factor score coefficient with the standardized data. The value of each factor score represents the importance of a given factor at the sample site. A factor score $>+1$ indicates intense influence by the process. Very negative values $(<-1)$ reflect areas virtually unaffected by the process while near - zero scores reflect areas with only moderate effect of the process. The spatial distribution of the factors (and hence the hydrochemical process represented by them) can be assessed by a contour of the factor scores representing each factor.

\section{RESULTS AND DISCUSSION}

Table 1 presents a univariate overview of the hydrochemical data of the study area. Result of factor analysis of the groundwater chemistry data $(n=60)$ indicates three trends (factors) that can be related to various controlling processes presumed to have produced the different water species. Table 2 shows the varimax rotated factor matrix consisting of the component factors, the loading of variables on each factor and percentage of data variance explained by each factor. These three factors account for $69.19 \%$ of the total variance in the dataset. Figures $3 \mathrm{a}-\mathrm{c}$ show an areal distribution of the intensity of the processes represented by each factor in Warri and environs.

Table 1: Univariate statistical overview of groundwater chemistry data from Warri and environs

\begin{tabular}{|l|l|l|l|l|}
\hline $\begin{array}{c}\text { Parameters } \\
(\mathbf{n}=\mathbf{6 0})\end{array}$ & Minimum & Maximum & Mean & $\begin{array}{c}\text { Std. } \\
\text { deviation }\end{array}$ \\
\hline $\mathrm{pH}$ & 5.30 & 9.10 & 7.88 & 0.95 \\
\hline $\mathrm{TDS}$ & 18.00 & 835.00 & 173.38 & 152.20 \\
\hline $\mathrm{Na}$ & 1.69 & 111.10 & 11.87 & 15.10 \\
\hline $\mathrm{K}$ & 1.50 & 76.44 & 11.53 & 12.33 \\
\hline $\mathrm{Ca}$ & 9.62 & 169.93 & 49.93 & 31.85 \\
\hline $\mathrm{Mg}$ & 1.92 & 26.92 & 5.45 & 4.59 \\
\hline $\mathrm{SO} 4$ & 0.00 & 0.30 & 0.07 & 0.05 \\
\hline $\mathrm{Cl}$ & 28.10 & 234.30 & 70.20 & 41.33 \\
\hline $\mathrm{HCO} 3$ & 12.20 & 414.80 & 80.23 & 68.53 \\
\hline
\end{tabular}

Table 2: Varimax rotated factor loading matrix for groundwater chemistry data in Warri and environs

\begin{tabular}{|l|c|c|c|}
\hline \multicolumn{1}{|c|}{ Variables } & Factor1 & Factor 2 & Factor 3 \\
\hline $\mathrm{PH}$ & 0.068 & 0.816 & 0.055 \\
\hline $\mathrm{TDS}$ & 0.0657 & 0.450 & 0.047 \\
\hline $\mathrm{Na}$ & 0.781 & -0.234 & 0.046 \\
\hline $\mathrm{K}$ & 0.873 & 0.253 & -0.008 \\
\hline $\mathrm{Ca}$ & 0.518 & 0.613 & -0.176 \\
\hline $\mathrm{Mg}$ & 0.059 & 0.651 & 0.043 \\
\hline $\mathrm{SO}_{4}$ & 0.071 & 0.015 & 0.975 \\
\hline $\mathrm{Cl}$ & 0.703 & 0.372 & 0.087 \\
\hline $\mathrm{HCO}_{3}$ & 0.500 & 0.631 & -0.276 \\
\hline Explained variance & 31.42 & 25.83 & 11.94 \\
\hline $\mathrm{Cumulative} \%$ of variance & 31.42 & 57.25 & 69.19 \\
\hline
\end{tabular}

Factor 1 has a high loading of $\mathrm{K}, \mathrm{Na}, \mathrm{Cl}$ and TDS and explains $31.42 \%$ of the total variance (Table 2 ). The concentration of $\mathrm{K}, \mathrm{Na}$ and $\mathrm{Cl}$ in seawater is much greater than in continental water. This factor can be ascribed to the intrusion of seawater into the aquifer system which increases the concentrations of these ions and hence values of the dissolved solids. The areal distribution of the factor scores (Figure 3a) show that the intensity of saltwater activity decreases away from the banks of River Warri. This suggests that saltwater ingress into the aquifer was predominantly related to water recharge from this tideinfluenced river. A small zone in the south-central portion of town shows exceptionally high scores. This area is the most densely populated and consequently witnesses higher groundwater abstraction. This probably establishes local freshwater depression cones, which induces saltwater infiltration into this area. This chloride water type is widely reported within the coastal tract of Nigeria (Etu-Efeotor, 1981; Udom et al,1999). Ca and $\mathrm{HCO}_{3}$ load secondarily on factor 1 .

Factor 2, which explains $25.83 \%$ of the total variance, includes $\mathrm{Mg}, \mathrm{Ca}, \mathrm{HCO}_{3}$ and $\mathrm{pH}($ Table 2). This factor reflects the signatures of natural water recharge and water-soil/ rock interaction. Surface water charged with atmospheric and biogenic $\mathrm{CO}_{2}$ infiltrates into the subsurface and aggressively attack aluminosilicates including feldspars and micas present in the formation liberating cations such as $\mathrm{Ca}$ and $\mathrm{Mg}$ into the water and leaving residues of clay minerals. A consequence of this incongruent dissolution is a rise in $\mathrm{pH}$ and in $\mathrm{HCO}_{3}$ concentration of the water (Freeze and Cherry, 1979)

The proximity of the Niger delta to the sea fosters a high rainfall in the region. This coupled with the high temperatures, encourages rapid chemical weathering and the liberation of cations into groundwater. Nonetheless, the areal distribution of the factor scores of factor 2 


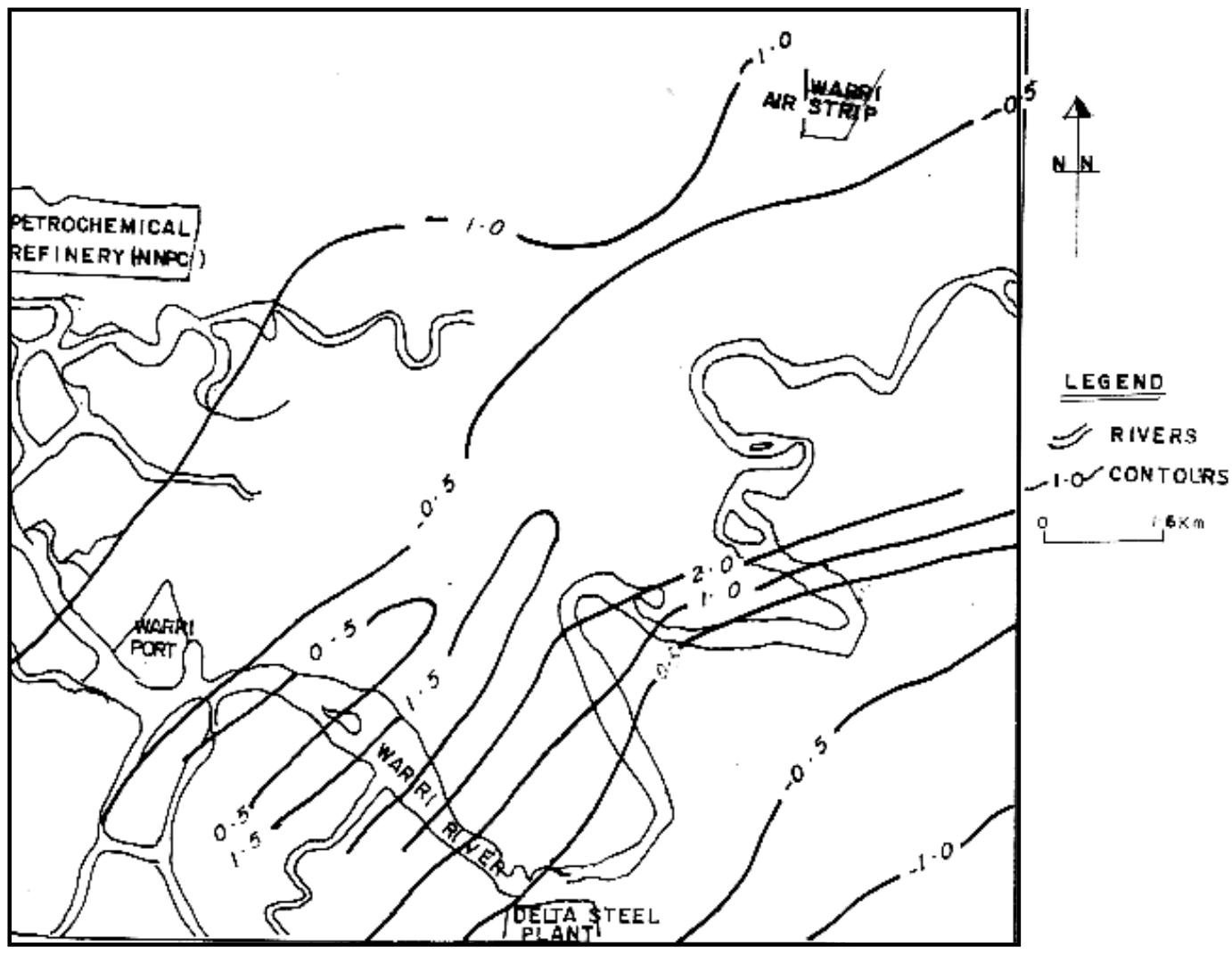

Figure 3a:Areal Distribution of Factor Scores for Factor 1 within Warri and Environs

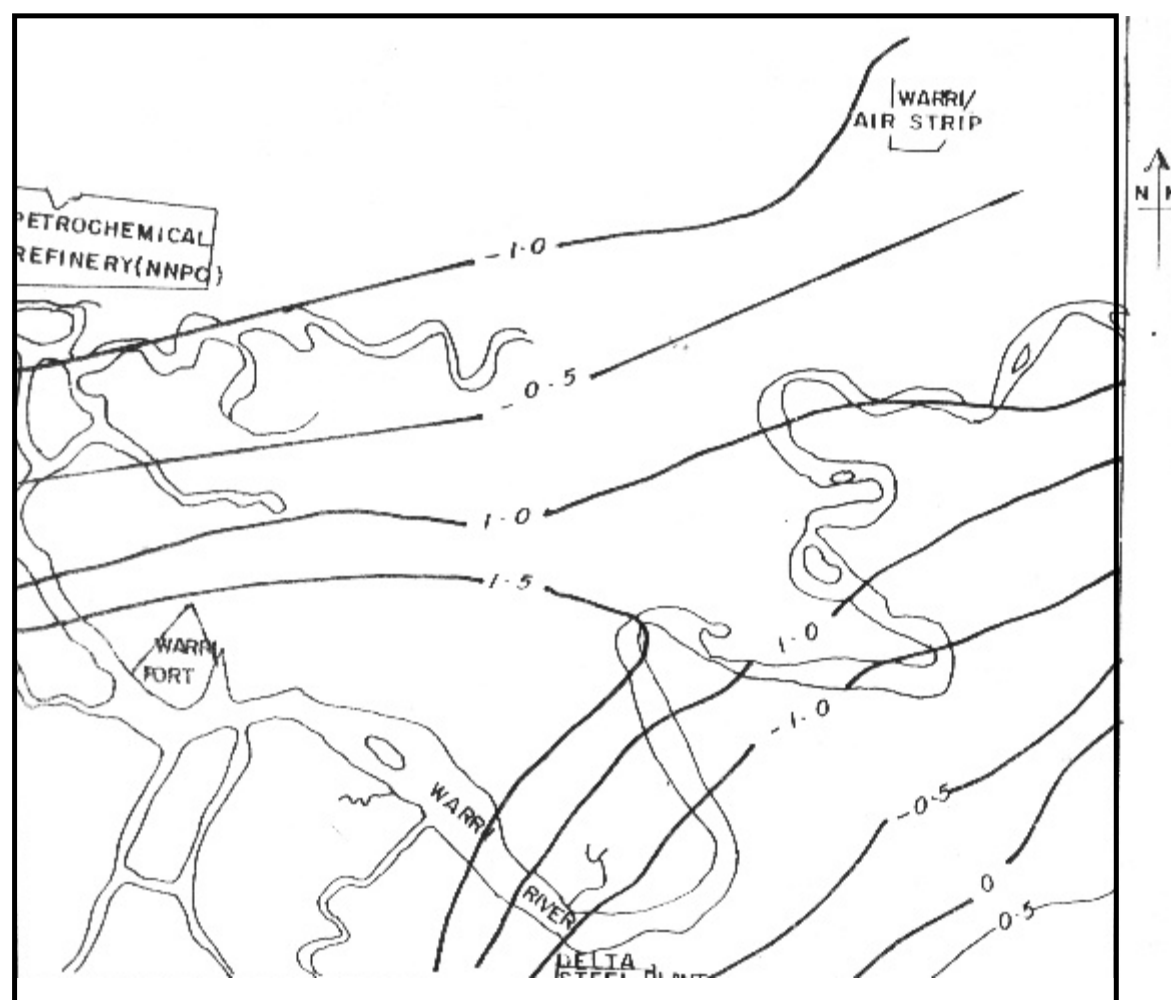

Figure 3b: Areal Distribution of Factor Scores for Factor 2 within Warri and Environs 


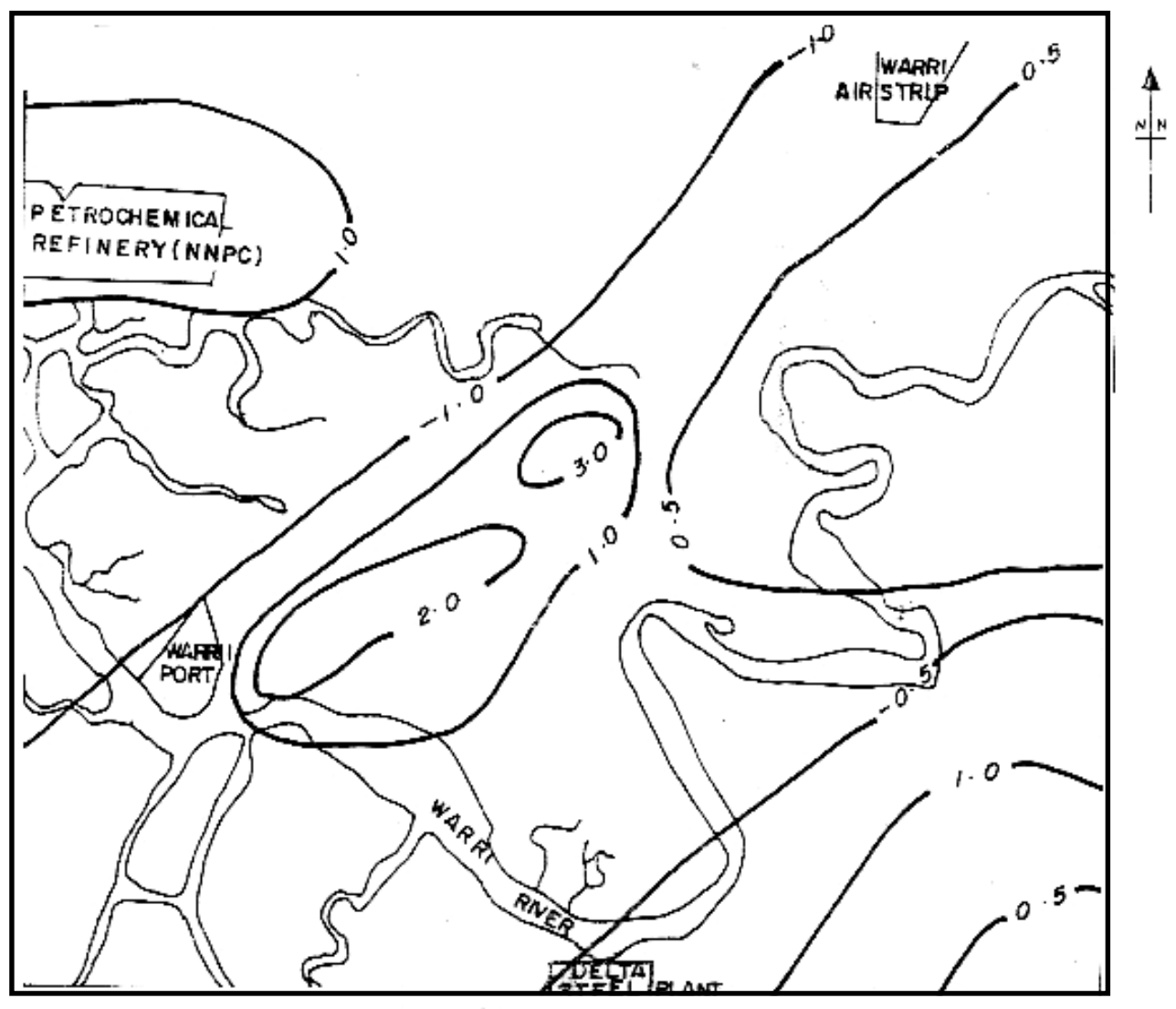

Figure 3c: Areal Distribution of Factor Scores for Factor 3 within Warri and Environs

(Figure $3 b$ ) reveal generally enhanced values near the banks of River Warri similar to that exhibited by factor 1 . This similarity in distribution pattern of the scores of Factors 1 and 2 suggest a mixing of the water species represented by the two factors. Figure 2 indicates that groundwater flow in Warri is bi-directional. Infiltrating rain recharge water dominated by $\mathrm{Ca}, \mathrm{Mg}$ and $\mathrm{HCO}_{3}$ flows in the aquifer towards the river valley. More saline river water rich in $\mathrm{K}, \mathrm{Na}$ and $\mathrm{Cl}$ percolates the aquifer and flows in the opposite direction, most especially during high tide. A mixing zone of the saline infiltrating river water and the normal shallow fresh groundwater is thus established away from the banks of the river. This interpretation is corroborated by the secondary loadings of $\mathrm{Ca}$ and $\mathrm{HCO}_{3}$ on Factor 1, and $\mathrm{K}$ and $\mathrm{Cl}$ on Factor 2.

Factor 3 explains $11.94 \%$ of the total variance and includes $\mathrm{SO}_{4}$. The areal distribution of its factor scores indicate high values in three isolated areas; the northwest fringe(around the petrochemical refinery), the southeast and the central portions of the town (Figure 3c). Although $\mathrm{SO}_{4}$ concentration is more enhanced in seawater than freshwater, the distribution of its factor scores indicate low to negative values in sample points with high scores of factor 1. Also, $\mathrm{SO}_{4}$ shows poor correlation with $\mathrm{K}(\mathrm{r}=$ 0.074), $\mathrm{Ca}(\mathrm{r}=-0.077)$ and $\mathrm{Cl}(\mathrm{r}=0.095)$. These indicate that the derivation of $\mathrm{SO}_{4}$ is more related to other processes than extraction from seawater.

The Deltaic Plain Sands is a sequence of sands and silt with local intercalation of peat, peaty and sulphur-rich clays. The dissolution of sulphides such as pyrite from the interstratified materials by percolating water produces $\mathrm{SO}_{4}$ ions in water. This probably explains the source of the high $\mathrm{SO}_{4}$ values in the southeastern portion of the town. On the other hand, the high $\mathrm{SO}_{4}$ scores recorded in the central and northwestern(around the petroleum refinery) portions of the town could be related to heavy vehicular activities and the petroleum refining process. The high scores of $\mathrm{SO}_{4}$ recorded in the central portion coincide broadly with the zone of highest vehicular traffic in the town. Gaseous emanations from the vehicles contain significant amounts of sulphur-rich gases. The petroleum refining company is another major contributor of sulphur- 
rich gases into the atmosphere through emissions during the refining process. The relative calm atmosphere coupled with constant rainfall in the town ensures that much of the emitted substances are not carried far from these vicinities before they are scavenged out of the atmosphere as acid rain and recharges the aquifer. Recent studies have shown that $\mathrm{SO}_{4}$ contribution to free acidity in Warri rainfall water is high and could be up to $76 \%$, far higher than what obtains in non-anthropogenically impacted zones (Ogunkoya and Efi, 2003).

\section{CONCLUDINGREMARKS}

The result of the multivariate statistical analysis, as applied to the chemical data set of groundwater in the Warri area provides an insight into the underlying controlling hydrochemical processes in the area. Three factors including factor $1(\mathrm{~K}, \mathrm{Na}, \mathrm{Cl}$ and $\mathrm{EC})$, factor $2(\mathrm{Mg}, \mathrm{Ca}$, $\mathrm{HCO}_{3}$ and $\left.\mathrm{pH}\right)$ and factor $3\left(\mathrm{SO}_{4}\right)$ extracted from the dataset represent the signatures of saltwater incursion, interaction with the geological matrix and dissolution of sulphur related compounds respectively in the groundwater. Factors 1 and 2 represent ions with dominant concentrations and therefore the main contributors to the groundwater salinity. The spatial distributions of these two factors indicate a zone of mixing of the two water types especially close to the bank of River Warri. Perhaps of greater significance is the decrease in intensity of the two dominant factors away from the banks of River Warri. This indicates a decrease in the concentration of ions( $\mathrm{K}$, $\mathrm{Na}, \mathrm{Cl}, \mathrm{Mg}, \mathrm{Ca}$ and $\mathrm{HCO} 3$ ) that are predominantly responsible for the salinity of groundwater away from the banks. The implication of this is that groundwater quality improves away from the banks of River Warri.

This inference is instructive for water resource developers in Warri and environs. The recent drive towards industrialization and the attendant urbanization means a greater demand for groundwater in the area. New groundwater abstraction schemes are recommended preferably in areas with low values of factors 1 and 2 (i.e. away from the banks of River Warri).

This paper demonstrates the effectiveness of factor analysis in sorting out otherwise ambiguous hydrogeochemical processes and in showing the spatial influence of such processes.

\section{REFERENCES}

Allen, J.R.L., 1965. Late Quaternary Niger delta and adjacent areas: sedimentary environments and lithofacies. Bull. AAPG 49, 547-600.
American Public Health Association. 1985. Standard methods for the examination of water and wastewater. APHA, New York.

Briz-Kishore B.H. and Murali, G., 1992. Factor analysis for revealing hydrochemical characteristics of a water shed. Environ. Geol. 19,3-9.

Chebotarev, I. J., 1955. Metamorphism of natural water in the crust of weathering. Geochem. Cosmochim. Acta. $8,22-212$

Dalton, M.G. and Upchurch, S.B., 1978. Interpretation of hydrochemical facies by factor analysis. Groundwater 16/4, 228-233.

Davis, J.C., 1973. Statistics and data analysis in geology. John Wiley and Sons, Inc., New York 550pp.

Davis, S.N. and De Wiest, R.J.M, 1966. Hydrology. Wiley, New York.

Etu-Efeotor, J.O., 1981. Preliminary hydrochemical investigation of sub-surface waters in part of the Niger Delta. Jour. Min. Geol. 18/1, 103-105

Freeze, R.A. and Cherry, J.A., 1979. Groundwater. PrenticeHall, inc, New-jersey. 604pp

Harman, H.H., 1960. Modern factor analysis. University of Chicago Press.

Hem,J.D., 1989. The study and interpretation of the chemical characteristics of natural water. $3^{\text {rd }}$ edn. USGS Water Supply Paper 2254, US Geological Survey.

Iloeje, N.P. (1981). A new geography of Nigeria. Longman, Nigeria.

Kaiser, H.F., 1958. The varimax criterion for analytic rotation in factor analysis. Psychometrika 23, 187-200

Lawrence, F.W. and Upchurch, S.B., 1983. Identification of recharge areas using geochemical factor analysis. Groundwater 20, 680-687

Nie, N.J., Hull, C. H., Jenkins, J G., Steinbrenner, K. and Brent, D.H., 1975. Statistical package for the social sciences. McGraw-Hill Book Co., Inc., New York. $2^{\text {nd }}$ Ed., 675pp

Offodile, M.E., 1991. An approach to groundwater study and development in Nigeria. Mecon Services Ltd., Jos , Nigeria. 245pp

Olobaniyi, S.B.and Owoyemi, F.B. (in press). Quality of groundwater in the Deltaic Plain Sands aquifer of Warri and Environs, Delta State, Nigeria. Water ResourcesJour. Nigerian Ass. Hydrogeologists.

Ogunkoya, O.O. and Efi, E.J., 2003. Rainfall quality and sources of rainwater acidity in Warri area of the Niger Delta, Nigeria. Jour. Min. Geol. 39(2), 125-130.

Piper, A.M., 1944. A graphic procedurein the geochemical interpretation of water analysis. Trans. Am. Geophys. Union 25, 914-923.

Raji, B. A. and Alagbe, S. A., 1997. A topo-geochemical sequence study of groundwater in Asa drainage basin, Kwara state, Nigeria. Environ. Geol. 39(6),544-548. 
Reyment, R.A., 1965. Aspects of the geology of Nigeria. Ibadan University Press. 145pp.

Schoeller, H., 1962. Les eaux souterraines. Masson \& Cie, Paris 642pp.

Short, K.C. and Stauble, A.J., 1967. Outline of the geology of the Niger delta. Bull. AAPG 51, 761-779.

Stiff, H.A.,Jr. 1951. The interpretation of chemical water analysis by means of patterns. Jour. Petrol. Technol. 3, 15-17.

Subbarao, C. Subbarao, N.V. and Chandu, S.N., 1995. Characterization of groundwater contamination using factor analysis. Environ. Geol. 28(4),175-179.
Todd, D.K., 1980. Groundwater hydrology. Wiley, New York.Udom, G.J., Etu-Efeotor, J.O. and Esu, E.O. 1999. Hydrochemical evaluation of groundwater in parts of Port Harcourt and Tai-Eleme local government areas, River State. Global Jour. Pure and Appl. Sc. 5/5, 545551.

Weber, K. J. and Daukuro, E., 1975. Petroleum geology of the Niger delta. Proc. $9^{\text {th }}$ Petroleum Congress, Tokyo. pp209-229 Wigwe, G. A., 1975. The Niger delta: Physical. In G.E.K. Ofomata (ed.) Nigeria in maps: Eastern states. Ethiope Publ. House, Benin . pp 3840. 